\title{
REVIEW I Cultural Mapping and Musical Diversity
}

\author{
Edited by Britta Sweers and Sarah M. Ross
}

Sheffield and Bristol, CT: Equinox, 2020

ISBN 9781781797594 (PB)

\author{
Antti-Ville Kärjä \\ University of the Arts Helsinki, Finland \\ antti-ville.karja@uniarts.fi
}

As scholarly literature on music as heritage increases, two issues have emerged to intrigue me. First, there are societal questions about the politicization of the notion of heritage, whether what is at stake is strategic celebration of ethnic minorities within authoritarian regimes or more insidious reemergence of ethnonationalist ideologies. Second, from an academic stance, I have noticed a growing suspicion in me that the discussion evinces the dubious distinction between ethnomusicology and popular music studies. These are, then, the preconceptions that guide my reading of Cultural Mapping and Musical Diversity, in response to the editors' invitation to "critical reflection, both within ethnomusicology and beyond" (8).

The volume has its genesis in the 2013 European Seminar of Ethnomusicology and comprises fifteen chapters divided in four parts, supported by a general introduction and four briefer partial ones. According to its title, the first part centres on cultural mapping as a method and includes individual contributions about disciplinary history on one hand and current practical solutions on the other. Yet in contrast to the emphasis laid in the introduction on cultural mapping as a critical tool in heritagization, the issue remains largely implicit in the chapters. For instance, Marcelo Sorce Keller's reconsideration of "old concepts" such as Kulturkreise, cultural areas and chronotope "for the mapping of music cultures today" (19) ultimately requires a fair deal of mental bridge-building on the part of the reader. The connection to cultural mapping is equally superficial in Svend Kjeldsen's chapter on the hybridity, social poetics and nostalgia in contemporary Mancunian Irish traditional music, and the same goes for Pekka Suutari's take on ethnicity, linguistic identity and generational dynamics in folk rock in Russian Karelia. Moreover, it is outright disappointing that in none of the first three chapters is cultural mapping mentioned even in passing, leading only to confusion over its qualities and analytical procedures in general.

IASPM Journal vol.10 no.2 (2020) 
Some relief is provided as Part I closes by Ana Hofman's scrutiny of inconvenient, contested or dissonant facets of music heritagization in post-Yugoslav socio-cultural circumstances, with an explicit reliance on critical heritage studies and the idea of "counter mapping" that derives from traditions of critical cartography. While such points of departure respond directly to the aims of the collection as stipulated in the general introduction, on the basis of the actual (and educating) treatment of Yugoslav partisan songs in relation to World-War-Two antifascism, the post-war socialist era and the more recent post-socialist developments, I continue to be perplexed as far as the methodological details of cultural mapping are concerned.

The second part carries the title "Cultural Landscape and Music", and the chapters deal with the interrelations between environmental conditions and cultural (re)definition and transformation, including musical change, both historically and in present-day settings. Here too the uncertainty of cultural mapping as an overarching theme of the collection prevails. In Lukas Park's take on the hua'er folk singing in the Gansu province of China, for instance, the issue becomes further convoluted as there is an apparent confusion between environment and landscape in the treatment. Ultimately, the chapter is more revealing about the political conditioning of research than its suggested topic. Shai Burstyn's "modest contribution" (109) on climate and environment in Abraham Zvi Idelsohn's History of Hebrew Music in turn is no doubt appurtenant as a lesson about comparative musicology in the early twentieth century, yet the chapter stands out from others in its, indeed, modesty.

The remaining two chapters in this part are significantly more solid as theoretically informed analyses. First, Thomas Solomon writes about a pilgrimage in the Bolivian Andes and argues with compelling evidence that the discursive (or conceptual) construction of landscape becomes intertwined with embodied expression that involves producing instrumental sounds while moving about, as well as reverberations. Conspicuously enough he is the first in this book to utilize visual two-dimensional maps in his analysis, even though the conceptual linkage to cultural mapping remains implicit.

Second, regarding the gong culture of the Ede people in the Central Highlands of Vietnam, Vincenzo della Ratta educatively discusses the gallimaufry of heritagization by elaborating on the interrelations between "traditional rituals, neotraditional ceremonies, and extra-traditional events" (154). The last of these is of primary importance in relation to heritage tourism, implicated also in processes of selective preservation, folklorization, hybridization, desacralization, instrumentalization and spectacularization. Such a list of 'izations' bears connections to conventional topics of popular music studies, yet instead of interrogating the connections in detail, a performance for tourists is discussed somewhat deprecatingly in relation to the emergence of so-called neotraditional music implicated in overt socialist political regulation.

The core topic of Parts III and IV of the volume is intangible cultural heritage $(\mathrm{ICH})$. The chapters in the third part concentrate on historical archival policies, issues of official interpretations on the national level, and disparities between governmental policies and ideals of cultural sustainability. While in this part's introduction the institutional connections between $\mathrm{ICH}$ politics and cultural mapping are emphasised on the basis of UNESCO policies, the actual utilization of cultural mapping in the chapters grows increasingly thin. A case in point is the chapter by Marc-Antoine Camp, Brigitte Bachmann-Geiser, David Vitali, Dieter Ringli and Patricia Jäggi on "mapping and representing musical diversity in 
Switzerland" (210), as its title goes. Yet the term "mapping" does not surface in the text body. Otherwise the chapter is intriguing enough in its polyvocal juxtaposition between artistic, scholarly and official angles. The authors also make pertinent remarks concerning the temporal relations in deeming something a living tradition, particularly in relation to the tendency to exclude pop and rock practices from the $\mathrm{ICH}$ lists.

In the other chapters of Part III, Gerda Lechtleitner discusses appropriately the interconnections between UNESCO and archives; Marzanna Poplawska describes the ratification of the 2003 UNESCO ICH convention in Poland, though surprisingly with only tangential references to music; and Sarah M. Ross examines the interconnections between $\mathrm{ICH}$ and cultural sustainability in the context of Swiss synagogue music. Of these, only Lechtleitner mentions mapping and not until the chapter conclusion; in addition, the superficiality of its incorporation suggests a certain degree of artificial editorial inclusion. To this end, it is revealing that in her chapter, co-editor Ross avoids the notion of cultural mapping altogether.

In Part IV, the discussion proceeds towards ethnographic approaches through three case studies. As many of the chapters in the volume can be conceived equally as case studies with a pronounced interest in music heritagization, the separation of these three into a section of its own comes across as technical rather than thematic. This notwithstanding, Matthew Machin-Autenrieth's excavation into the dynamics of regionalization on a subnational level in the context of Andalusian flamenco and Thomas Beardslee's critical take on the discrepancies between safeguarding policies and resources, or "capabilities", are thought-provoking in their emphasis on the entanglements between policy-making, education and cultural industries in the case of the former and, as regards the latter, on "the safeguarding of real human well-being and freedoms, rather than the safeguarding of a constructed vision of 'intangible cultural heritage'" (279). The collection closes with Zuzana Jurková's informative even if mainly descriptive rundown of the multilayered perception of a UNESCO ICH inscription, namely the Slovácko verbuňk dance as it is practiced in the present-day Czech Republic.

On the whole, Cultural Mapping and Musical Diversity offers edifying evidence of the unending variety of music heritagization, as well as of the constraints of disciplinary boundaries. This is in no small part because of conceptualizing ethnomusicology primarily as a form of ethnographic - instead of, say, cultural study of music. As a consequence, I surmise, it is easy to avoid reading across the boundaries at issue, even if many chapters in the volume point to porous genre boundaries, not to mention popular music in the axiomatic sense. This raises also the issue of how to edit a volume; judging by occasional blurry graphics, recirculation of material and absence of references to most recent ethnomusicological literature, I cannot but wonder how it has taken seven years to finish the collection. Instead of having what I perceive as expanded conference proceedings with an inconsistent degree of revision, I am confident that readers, editors, publishers and authors alike would benefit from an investment in securing coherence at the expense of coverage. Mentioning publishers, institutions surely play their part here, leading to conjectures whether the often perfunctory references to cultural mapping in the chapters indicate a purpose-oriented utilization of it, and $\mathrm{ICH}$ in more general, as a promotional slogan of sorts. On the basis of such guesswork, I am increasingly convinced that heritagization functions as popularization, yet equally desperately still seeking for analyses where this is addressed on a conceptual level, both within ethnomusicology and beyond. 